\title{
NEW OBSERVATIONS ON THE DISTRIBUTION AND MORPHOLOGY OF THE AMPHIPOD, GAMMARUS ZADDACHI SEXTON, WITH NOTES ON RELATED SPECIES
}

\author{
By Sven G. Segerstråle \\ From the Zoological Museum of the University and the Laboratorium Hydrobiologicum \\ Soc. Scient. Fennicae, Helsinki-Helsingfors, Finland
}

(Text-figs. I-7)

Editor's Note. This paper and that by Mr G. M. Spooner (this fournal, pp. I-52), independently bringing forward certain new ideas on the taxonomy of Gammarus zaddachi and $G$. locusta, were received for publication simultaneously. As Mr Spooner's paper is a report of work largely carried out before the war, of which summarized results have already been referred to in print (e.g. Report of Council in this fournal, Vol. xxIv, pp. 444, 69I; Huxley, The Modern Synthesis, p. 315), it is given precedence. The authors have since consulted each other over matters in which their contributions overlap, in particular over the taxonomic status of the new forms they distinguish and regarding the names to be applied to them. Dr Segerstråle has kindly consented to adopt the two new names introduced above by $\mathrm{Mr}$ Spooner, and to make considerable alterations to his original manuscript.

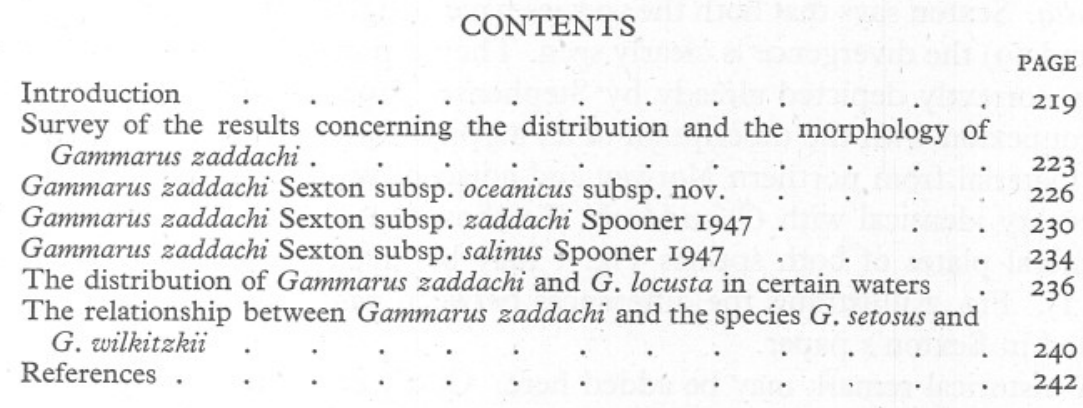

\section{INTRODUCTION}

As is well known, the species Gammarus zaddachi, established by E. W. Sexton in 1912 on material from European brackish and fresh-water localities, has caused great confusion among zoologists, as the characteristics distinguishing it from various related species, particularly Gammarus locusta, G. duebeni and G. pulex, have been very frequently disregarded. This confusion still persists to-day - that is amply shown by the material received for the present investigations from various museums.

In view of the drawbacks brought about by this confusion, not the least on account of the fact that $G$. zaddachi has been accepted as a typical salinity indicator in ecological work while, on the other hand, G. locusta is a favourite 
object for physiological investigations on osmotic regulation in water animals, zoologists are deeply indebted to Mrs Sexton for a paper, published in this fournal in 1942, the aim of which was to clear up the problems that have arisen around G. zaddachi. In this paper the author discussed the whole literature on the subject, and was in many cases able to correct previous errors by re-examining the original material. In addition, the author gave a new detailed description of the two forms of the species, the 'saline' and the strikingly hairy 'fresh-water' one, accompanied by numerous excellent figures. Finally, the paper contained a comparison between G. zaddachi and the species with which it has most often been confused.

The main differences between zaddachi and locusta mentioned, and as a rule depicted in Sexton's paper, refer to the setose armature of the peduncle of antenna I (in zaddachi, numerous clusters of well-developed hairs present; in locusta, the peduncle almost glabrous); to the shape of gnathopod 2 (in locusta, narrower proportionately, etc.); to the shape of side-plate 4 (in zaddachi, inferior margin almost semicircular; in locusta, lower portion deep and almost rectangular); to the epimeral plates 2 and 3 (in zaddachi, hind-corners subacute; in locusta, acutely produced); to the pleon segments 4-6 (in zaddachi, dorsal humps only slightly raised; in locusta, elevated and prominent); etc.

A characteristic referring to the head sinus should be added to these principal points of difference. In zaddachi the sinus is much deeper than in locusta. Sexton says that both the species have a slight sinus, but in her figures ( $\mathrm{I}$ and I9) the divergence is clearly seen. The deep head sinus in zaddachi has been correctly depicted already by Stephensen (I940, fig. 40, I, II, p. 3I7), in connexion with the description of an atypical form of locusta, occurring in his material from northern Norway and adjacent waters; as seen below, it is in reality identical with G. zaddachi. To show the difference in shape of the epimeral plates of both species Fig. I may be given (cf. also Sexton's textfig. I). Fig. 2 illustrates the differences between zaddachi and duebeni, mentioned in Sexton's paper.

A historical remark may be added here. Oddly enough, it seems probable that the species nowadays regarded as the true locusta is not identical with the form found by Linnaeus in I74I on the seashore at Gothland and named by him (in 1745) Cancer macrourus coeruleus, and later on (176I, etc.) C. locusta, but rather that he had had to do with Gammarus zaddachi. The famous naturalist points out in his description that the last pair of legs had the inner ramus shorter than the outer. As the difference in length is very small in the 'modern' G. locusta, but in G. zaddachi constitutes one of the most striking characteristics, and, furthermore, as zaddachi occurs very commonly together with locusta on the shores of Gothland (see below, pp. 236-9), it appears definitely more probable that the amphipod observed by Linnaeus belonged to zaddachi. A similar view has already been expressed by the Swedish zoologist Liljeborg. In his account of the Scandinavian species of the genus Gammarus (I855) he 
emphasized that the species meant by Linnaeus was obviously not $G$. locusta $M$. Edwards (in which the rami of the last uropods are, as in the locusta of the present day [depicted by Sars etc.], 'presque égaux entre eux' [M. Edwards, I840, p. 45]). He therefore gives this species the name mutatus and regards the 'locusta' found in the Baltic by Zaddach (1844, I878), i.e. the same which in I9I2 was called G. zaddachi by Sexton, as Linnaeus's species. In the diagnosis of the two species Liljeborg especially points out the differences in the relative length of the inner ramus of the last uropods, giving for mutatus 'rami pedum spuriorum ultimorum circiter aequales' and for locusta 'rami
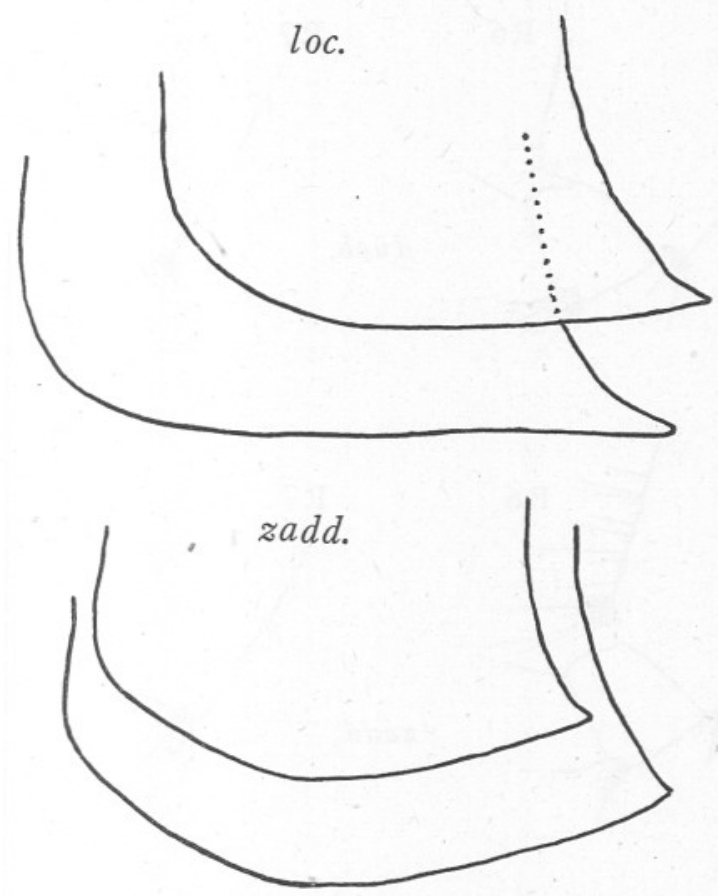

Fig. I. Second epimeral plates of Gammarus zaddachi and G. locusta (two of each; males), to show the difference in shape of hind-corner. Setae and spines omitted. Material from the Baltic.

pedum spuriorum ultimorum insigniter inaequales, interior exteriore saltem tertia parte minor'.

The fact that already Liljeborg separated the two forms of Gammarus mentioned above into distinct species, may, if only the priority of the nomenclature suggested by him is taken into consideration, motivate changing of the names locusta and zaddachi, used nowadays, into mutatus and locusta respectively. But in view of the great new confusion which no doubt would be the consequence of this change, the present author has the decided opinion that 
the modern names should be retained as 'nomina conservanda'. This idea is supported by the fact that Liljeborg erroneously listed the independent species $G$. duebeni as synonymous to $G$. locusta, thus making the value of the diagnosis of this species somewhat doubtful.

In connexion with studies on the Gammarus fauna carried out in the Finnish coastal waters since 194I, the present author has obtained results which cast a new light on the distribution and ecological character of the saline form of

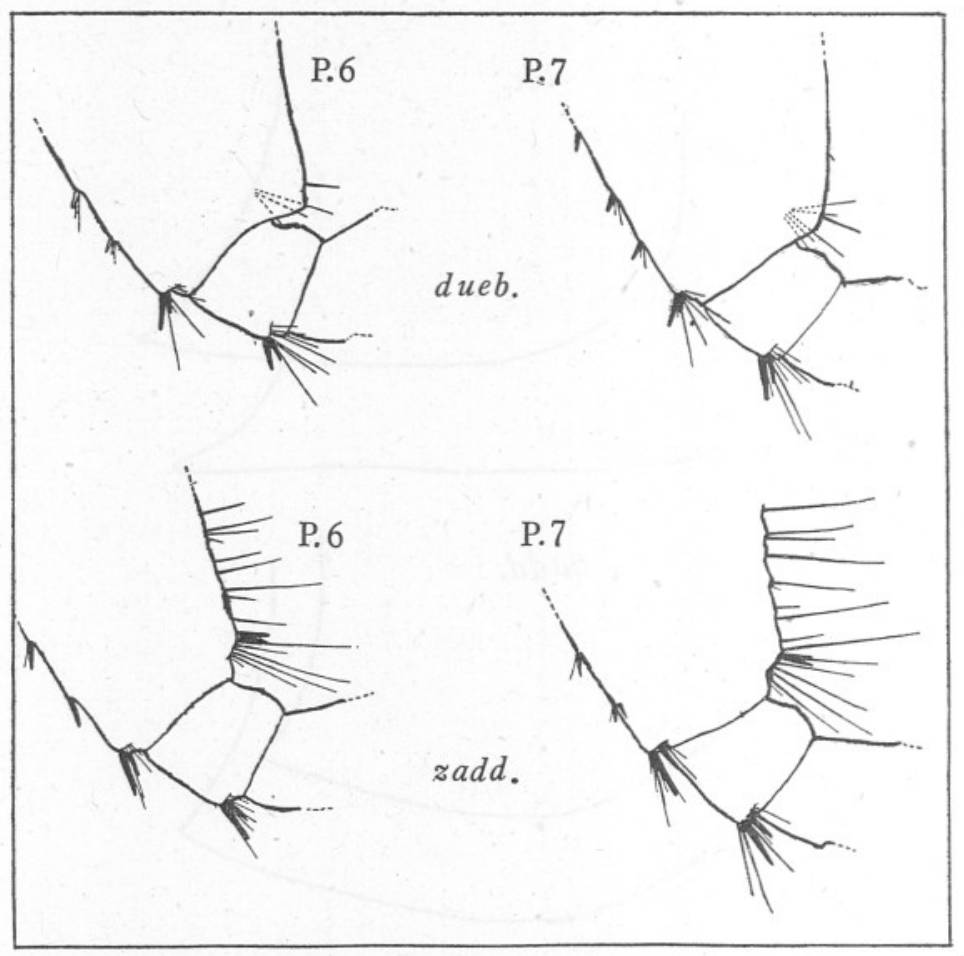

Fig. 2. Segments 2-4 of the peraeopods 6 and 7 of Gammarus duebeni and G. zaddachi freshwater form (=ssp. zaddachi, according to Spooner; see p. 5), to show the difference between these species in the shape of the postero-distal angle of the basal segment. In the former species this is much more produced (especially in the 6th peraeopod) and lacks the strong spines present in the latter. (From Segerstråle, I946.)

G. zaddachi and which also complete our knowledge of the morphology of this and the fresh-water form of the species in essential points. These results which, I hope, may considerably facilitate the recognition of G. zaddachi, are dealt with in the present paper. In connexion with this subject the relationship between $G$. zaddachi and the closely allied species $G$. setosus and G. wilkitzkii will be discussed. 
The author feels deeply indebted to Mrs E. W. Sexton (Marine Biological Laboratory, Plymouth) for her most valuable and kind help in sending material and discussing in letters questions concerning the subject. $\mathrm{He}$ is also indebted to the late Museumsinspektör K. Stephensen, of the Museum of Copenhagen, for his kindness in repeatedly supplying collections of Gammarus from Danish and Arctic waters. The other museums from which material was received for the present investigation, with the names of those to whom the author's thanks are similarly due, are as follows: Bergen Museum, Conservator H. Tambs-Lyche; British Museum, Dr Isabella Gordon; State Museum of Natural History, Stockholm, the late Prof. Dr Sixten Bock; Zoological Museum, Berlin, Prof. Dr Adolf Schellenberg. In addition, Mr D. M. Reid (Harrow) and Cand. phil. Erik Dahl (Lund) have kindly sent samples of various forms of Gammarus.

In total the material available embraces collections from the northern Atlantic and the Arctic (Massachusetts, Labrador, Greenland, Iceland, Norway, Spitsbergen, Murman Coast, Novaya Zemlya), the North Sea (Heligoland, coast of Denmark), the Cattegat, the waters around the Danish Isles, and the Baltic.

As mentioned already by Spooner, in his paper in this Fournal, pp. I-52 (see Editorial note, p. 219), the results obtained by him and by the present author partly overlap. Thus we have both distinguished Sexton's 'fresh-water form' from two other types of zaddachi and have described it. Thanks to the good offices of the Editor we have had the opportunity of going through our papers reciprocally before publication. The name $G$. zaddachi subspecies $z a d d a c h i$ given by Spooner to the above-mentioned form will be used also in the present paper. Another form found by both of us and designated subspecies salinus by Spooner will also be quoted here under his name. The third form which has been studied mainly by the present author will be described below as subspecies oceanicus.

The author wishes to present his thanks to $\mathrm{Mr}$ Spooner for most valuable comments and suggestions in letters.

\section{Survey of the Results CONCERning the Distribution AND MORPhology OF GAMMARUS ZADDACHI}

The distribution of the saline form. ${ }^{1}$ The saline form of $G$. zaddachi (also formerly called the brackish-water form by Sexton) has hitherto been recorded

1 As shown by Spooner, Sexton's 'saline form' of zaddachi embraces the subspecies salinus, erected by him, as well as the subspecies oceanicus, described for the first time in this paper. The 'saline form', spoken of here, refers to the latter subspecies. 
only from waters with reduced salinity (the southern coast of the Baltic and the estuary of the Elbe, etc.), and has consequently been regarded as a typical brackish-water animal. In reality, this form is, however, mainly marine as, besides being distributed in brackish water, it is also widely found in the northern Atlantic and the Arctic (Fig. 4). In the samples from these waters, labelled locusta, the saline form is extremely common, whereas the true locusta is almost entirely lacking (besides zaddachi the Arctic samples of 'locusta' frequently contain the species G. setosus and G. wilkitzkii). Structurally the form in question agrees strictly with the saline one living in the Baltic in all essential characteristics, the only difference being its size, which is much larger (body length up to $38 \mathrm{~mm}$.). ${ }^{1}$

The northernmost localities from which records of the true locusta originate are situated on the north-east coast of Iceland (Bakkafjordur; Cop. Mus.) and northern Norway (Loppa, c. $70 \frac{1}{2}^{\circ} \mathrm{N}$.; Stephensen, I940, p. 318). Thus, the species does not penetrate as far north as does the saline form of zaddachi. Locusta also does not nearly attain the same size as this form (maximum observed length of locusta 29 mm.; Stephensen, 1940, p. 318 ; a clear difference seen also in the Baltic). The previous literature records of Arctic specimens of $G$. locusta greater than $c$. $30 \mathrm{~mm}$. might consequently refer to the saline form of $G$. zaddachi (or to the likewise very large allied species G. setosus and G. wilkitzkii which also hitherto have frequently been determined as G. locusta). The saline form of $G$. zaddachi is very euryhaline; in this respect it distinctly surpasses $G$. locusta (for details, see pp. 236-8).

The existence in the northern marine areas of a very zaddachi-like form of G. locusta has already been realized by Stephensen. In the above-mentioned important paper on the Amphipoda of northern Norway and Spitsbergen with adjacent waters (1940), he points out that the material of G. locusta (by him named $G$. locusta locusta) included, besides the typical form, also a deviating one which was much more common in the collections, and which in certain respects agreed with G. zaddachi, particularly in the shape of the 4th side-plate. As the collections used for the present investigation contain a number of samples from Stephensen's material, the author has had the opportunity of examining them. The form discussed by Stephensen is a typical G. zaddachi, saline form. Stephensen's including it in the species of locusta is partly accounted for by the incorrect records of the head sinus in G. zaddachi given in previous literature.

The morphology of the saline and the fresh-water form. As is well known, the setose armature of the two forms differs greatly, as it is much more developed in the fresh-water form, especially on the hinder peraeopods, the pleon segments $4-6$, the telson, and the uropod 3. It is, however, striking that the difference in hairiness between the Ist antennae of both forms,

${ }^{1}$ The author's determination of the Baltic saline form has kindly been confirmed by Mrs Sexton. 
although generally quite distinct, has not been observed so far. ${ }^{1}$ This may probably be explained by the aim of the descriptions of zaddachi mainly having been to point out the characteristics which separate the species from locusta; with respect to the Ist antenna, namely, both forms of zaddachi clearly differ from this species. But, on the other hand, the comparatively poor hairiness of the antennae in typical saline specimens of zaddachi obviously gives it a resemblance to locusta great enough to cause confusion with this species. The difficulty of identification has been augmented by the shortness of the peduncle of the Ist antenna in the saline form, a characteristic which has also been overlooked.

The above-mentioned inequality in length of the peduncle of the Ist antenna shows that the view prevailing nowadays of the differences between the saline and the fresh-water form being confined to the strong hairiness of the latter is not correct as the structure of the two forms also differs. In addition, the present investigation has revealed a second structural disparity, viz. in the relative length of the 2 nd antenna in the fresh-water form being, in spite of the longer peduncle of the Ist antenna, distinctly greater than in the saline one.

Furthermore, the study of freshly captured animals from Finnish waters has shown that the body colour differs in the two forms of zaddachi. The difference is mainly caused by the existence in the fresh-water form of a pattern of transverse and longitudinal bands on the dorsal part of the body; in the saline form there is no pattern. Mrs Sexton's not having observed the divergence is due to the fact that her material consisted only of preserved animals; in alcohol and formol the pattern is completely deleted. ${ }^{2}$

Finally, the fresh-water form is smaller in size, even in comparison with the Baltic saline form which lives together with the former; if the large Arctic saline form is subjected to the comparison the difference is of course much more marked.

It may be added that the investigation of the comparatively extensive material available to the present author, containing among others the large Arctic specimens, has considerably widened the variation range for certain characteristics (number of spines on pleon segment 4-6, number of spines and setae on the telson, number of joints on the flagella of the antennae).

The 'combined' form. Transitional forms between the saline and the freshwater forms of $G$. zaddachi have previously been found by several authors,

1 Sexton (1942, p. 597) states: 'In all the animals, saline as well as freshwater, both peduncles and the flagella carry on the under margin dense tufts or clusters of long stiff outstanding setae, some of each cluster extending far beyond the rest.' Strictly, however, the records given (on pp. 597 and 600) of the number of hair clusters on the peduncle of antenna I, as well as of the length of the peduncle, hold good only for the fresh-water form.

I can now add that Spooner, too, has noted differences in setation of the antennae between the fresh-water and those 'saline' animals which are here called oceanicus.

2 As Sexton mentions (I942, p. 593) that 'the chitinous cuticle varies in the two forms, being thick, strong and opaque in the freshwater, thin and transparent in the brackish water specimens', this difference, according to records kindly given by Mrs Sexton to the present author in a letter, is obviously not real, but due to different preserving methods. 
mainly in the Baltic (Sexton, I9I2, I9I3; Schellenberg, I934; Höfken, I937; Dahl, I944). ${ }^{1}$ Specimens of this type are common also in the material from brackish areas available to the present author. Höfken emphasizes that these forms are not properly transitional, but combine characteristics of the saline and the fresh-water form (called by him G. locusta and G. zaddachi). This agrees with Dahl's statement that the specimens in his material from the Baltic, more or less intermediate between both forms (by him determined G. locusta f. locusta and f. zaddachi), have rather setose antennae (=freshwater characteristic) but otherwise are very sparsely provided with hairs (=saline characteristic). In the collections from the Baltic examined by the present author this peculiar combined type is abundant. It has proved to be identical with Spooner's subspecies salinus.

In the following account details will be given of the morphology and distribution of the different forms of zaddachi, as observed in the material studied (distribution records from other areas included).

As will be shown, the combination of the following characteristics is diagnostic of the new subspecies G. zaddachi oceanicus: (I) the shortness and sparse setation of the peduncle of antenna I; (2) the sparse setation of the hinder peraeopods, the pleon segments 4-6, and the telson. (In the description a characteristic from the last peraeopod and the telson has been chosen as indicator of the hairiness of the hinder parts of the body. With respect to this character, oceanicus shows almost complete agreement with salinus.)

Unless otherwise stated, the descriptions refer to the male (the female has been less thoroughly studied; most characteristics are somewhat less marked in this sex). The records given refer to specimens of at least c. $8 \mathrm{~mm}$. in length (in smaller animals the characteristics are mostly not fully developed). All measurements are taken from the tip of the rostrum to the insertion of the telson.

In the list of synonyms an asterisk designates that the author has had the opportunity of examining specimens used for the paper concerned.

Gammarus zaddachi Sexton subsp. oceanicus subsp.nov.

\section{SYNONYMS}

Sexton, I9I2, I9I3, I942; G. zaddachi; brackish-water or saline form in part., cf. footnote, p. 223.

*Stephensen, I917: G. locusta var. Zaddachi, in part.; intermediate form between G. locusta and G. locusta var. Zaddachi (in part.). I940: G. locusta locusta, in part.

${ }_{1}^{1}$ Also the form, found by Poulsen in Danish waters and determined G. zaddachi (Poulsen, I932, p. 6 and fig. 3), seems to belong to the intermediate type. According to Spooner (p. 35), in reality the animals regarded as intermediates by Sexton generally belong to the fresh-water form (=subsp. zaddachi Spooner). 
*Hellén, r9r9: G. locusta, in part.

*Blegvad, I922: G. locusta, in part.

*Segerstråle, I933: G. locusta (in part.). I944: G. locusta f. typica.

*Schellenberg, material sent to the author: G. locusta.

*Valovirta, I935: G. locusta f. typica.

Höfken, I937: G. locusta.

*Suomalainen, I939: G. locusta (in part.).

*Dahl, I944: G. locusta f. locusta.

\section{MORPHOLOGY}

Maximum size. Male: Arctic $38 \mathrm{~mm}$. (Stephensen, I940, pp. 318, 320; north Norway), Baltic $26 \mathrm{~mm}$. (Schellenberg, I934, p. II, records a ' $G$. locusta', captured near Kiel and measuring $32 \mathrm{~mm}$.; probably a male of G. zaddachi oceanicus). Female: Arctic $28 \mathrm{~mm}$. (Stephensen, I940, p. 319; north Norway), Baltic $22 \mathrm{~mm}$.

Body colour (studied in freshly captured specimens from Finnish waters). Greyish, yellowish, or greenish brown, semi-transparent; usually darker in the female. No dorsal pattern nor, usually, red spots of oil globules on the sides of pleon segments I-3.

Setose armature of peraeopods, pleon segments 4-6, telson, and uropods. Weak development of the setae, as seen in Sexton's figures (I942, saline form). Peraeopod 7, longest seta in subapical cluster on hind margin of segments 4 and 5 not surpassing tip of spines in the same cluster (Fig. $3 g$ in the present paper). ${ }^{1}$ Telson, longest apical seta shorter than distance from its insertion to tip of subbasal spines (Fig. $3 e, f) .^{2}$ In marine specimens the telson setae may be comparatively long and partly feathery (Fig. $3 f$ ).

Length of antenna 2 in percentages of antenna I, from 18 males, length I3-20 mm., from the Baltic, Iceland and Labrador; specimens with broken or regenerating flagella excluded: $68-77$, average $73 \%$.

Maximum number of segments in the flagella (body length in brackets):

\begin{tabular}{|c|c|c|}
\hline $\begin{aligned} \text { Antenna } \mathrm{I}: \text { primary flagellum } \\
\text { accessory flagellum }\end{aligned}$ & $\begin{array}{c}\text { Male } \\
57(3 \mathrm{Imm} .) \\
\text { Io }(3 \mathrm{I} \mathrm{mm} .)\end{array}$ & $\begin{array}{c}\text { Female } \\
38(25 \mathrm{~mm} .) \\
\text { II }(25 \mathrm{~mm} .)\end{array}$ \\
\hline Antenna 2 & 2I (33 mm.) & $22(25 \mathrm{~mm})$. \\
\hline
\end{tabular}

Length of peduncle segments of antenna I (Fig. $3 a-d$; segment I measured from tip of the rostrum to distal end of the segment). Ratio of length of segments 2 and 3 combined to that of segment I, from $I \cdot O: I$ to $I \cdot 3: I$, generally c. I.I:I. Length of segment 3,0.4-0.5 of that of segment 2. The end of the

1 The difference in hair development between $z$. zaddachi, on the one hand, and z. oceanicus and z. salinus, on the other, is more marked on the posterior than on the anterior margin of the hinder peraeopods.

${ }^{2}$ This method for measuring the seta concerned has been chosen instead of comparison with the corresponding spines in order to reduce the inaccuracy of results arising from the variability of the spine length. 

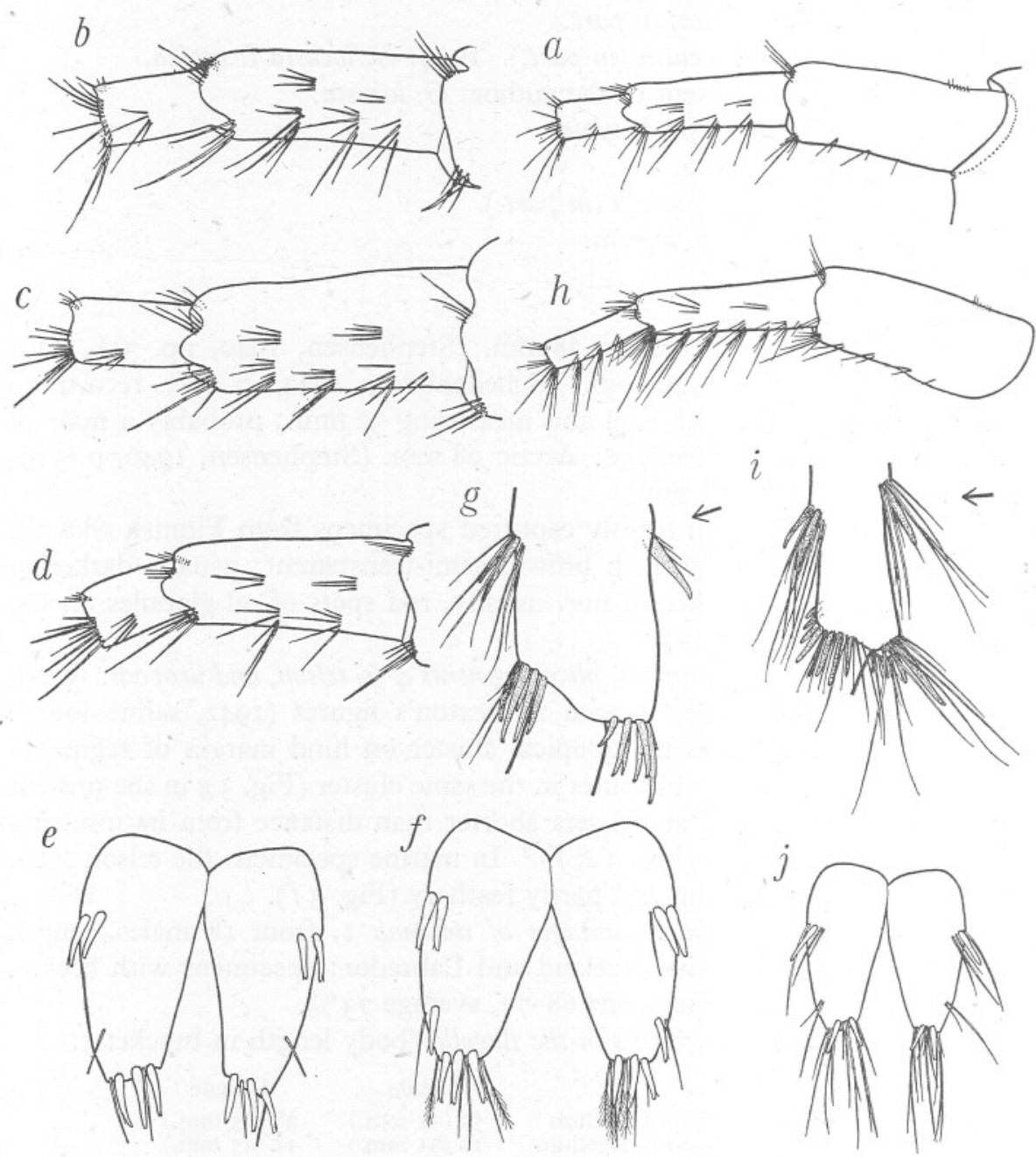

Fig. 3. Gammarus zaddachi (male). $a-g, z$. oceanicus; $h-j, z$. zaddachi. $a-d$, peduncle of iIst antenna (right, from the inner side; in $b-d$ only segments 2 and 3 depicted): $a$, south-west Finland (body length $\mathrm{I} 6 \mathrm{~mm}$.); $b$, north Norway (27 mm.); $c$, north Greenland (3I mm.); $d$, north Norway (27 mm.). e-f, telson: $e$, north Norway (26 mm.); $f$, Massachusetts (26 mm.). $g$, peraeopod 7, distal part of segment 5 and proximal part of segment 6 , west Greenland $(27 \mathrm{~mm}$.; the arrow shows the cluster used as a characteristic in the diagnosis; the specimen depicted has comparatively long setae on the anterior margin of segment). $h$, peduncle of Ist antenna, south Finland ( $16 \mathrm{~mm}$.). $i$, peraeopod 7 (for part depicted and arrow, see above), south Finland ( $19 \mathrm{~mm}$; the specimen has unusually short setae; for maximum length, see Sexton I942, fig. I2). $j$, telson, south Finland ( $18 \mathrm{~mm}$.). 
peduncle (when stretched forward, to continue the dorsal line) reaches at least as far as to the end of segment 4 of antenna 2 and at most to somewhat less than half the length of segment 5 , generally to about a quarter of this joint.

Number of hair clusters on the under-margin of peduncle segments 2 and 3 of antenna I (including apical cluster) (Fig. 3). Segment 2, 3-5, generally 4, clusters; segment 3, I-2.

Pleon segments 4-6, spine formula:

$$
\begin{array}{ll}
\text { 4th segment } & 3-6: 2: 3-6 \\
5 \text { th segment } & 3-5: 2: 3-5 \\
\text { 6th segment } & 2-3: 2: 2-3
\end{array}
$$

Telson, number of spines and setae:

$\begin{array}{lcc} & \text { Spines } & \text { Setae } \\ \text { Apical } & 3-4 & \mathrm{I}-5 \\ \text { Subapical } & 0-1 & 0-2 \\ \text { Subbasal } & \mathrm{I}-3 & 0-2\end{array}$

Uropod 3 inner ramus, length about three-quarters that of the outer, excepting in large marine specimens in which it may be up to seven-eighths. ${ }^{1}$

\section{ADDITIONAL NOTE}

The following differences between $z$. zaddachi and salinus observed by Spooner, have proved to exist also between the former subspecies and oceanicus (material from Finnish waters).

'As does salinus, oceanicus differs from $z$. zaddach $i$ in the following respects:

(I) accessory flagellum, number of segments and length somewhat greater;

(2) gnathopod 2, a little narrower and hinder margin clearly bulging (in

z. zaddachi almost straight); (3) epimeral plate 3, posterior distal angle distinctly more acutely produced (epimeral plate 2, difference less pronounced); (4) distal segments of last peraeopod, somewhat more slender; (5) last uropod, inner ramus a little longer. The measurements-certainly few in number-of characteristics I, 4 and 5 fall within or very near the variation limits given by Spooner for $z$. zaddachi and salinus. ${ }^{2}$

\section{DisTRIBUTION}

The form in question is widely spread in the northern Atlantic (material from waters south of the North Sea not available) and in the Arctic, but occurs abundantly also in the brackish water of the Baltic (observed minimum salinity in places of capture c. $2.5 \%$ ) (see map of the Baltic in Fig. 6; for details see p. 236). ${ }^{3}$ Depth records: $0-25 \mathrm{~m}$.

${ }^{1}$ It is a common feature in the amphipods that the inner ramus of the last uropods increases with age, as is well known.

${ }_{2}$ The author has not found calceoli in the (mature) female of $z$. zaddachi. These organs were lacking also in the examined females of oceanicus (Spooner mentions that he often found calceoli in the female of $z$. salinus but not of $z$. zaddachi).

3 Spooner has now shown (p. 43) that the subspecies in question occurs also in northern Scotland. 


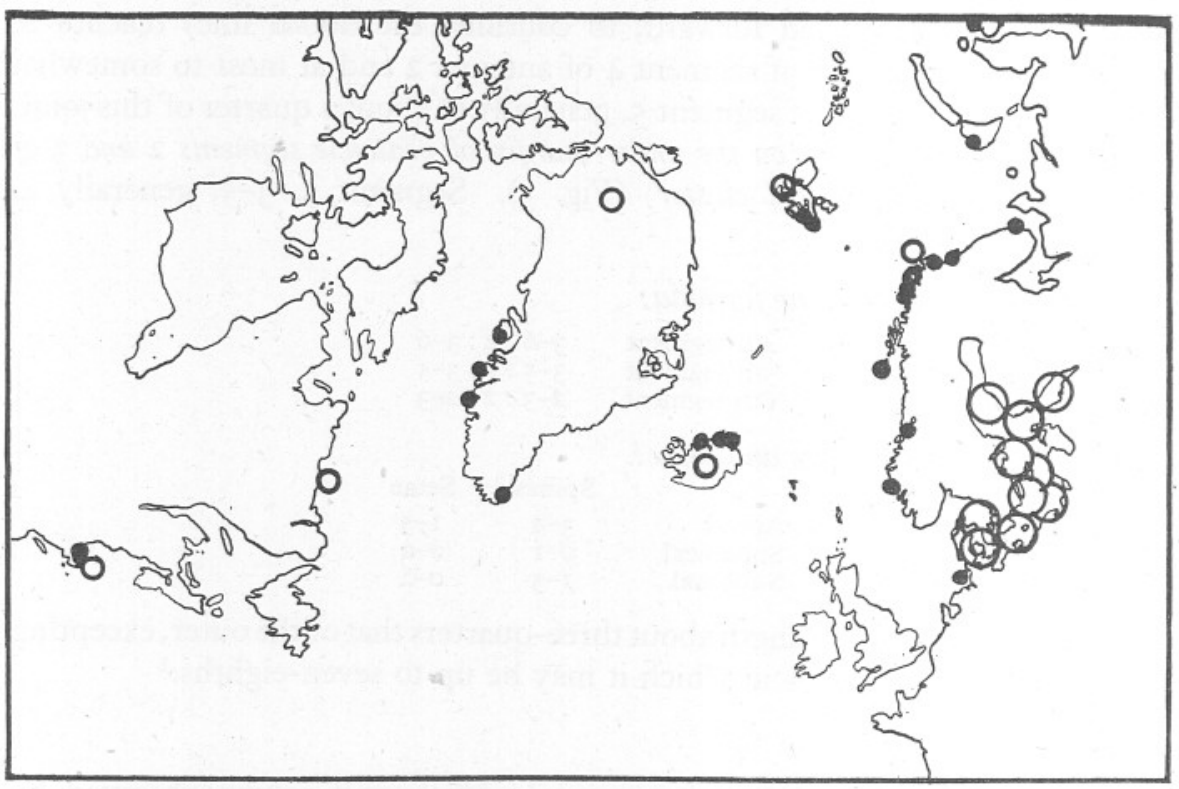

Fig. 4. The distribution of Gammarus zaddachi oceanicus according to the material investigated (samples not available from waters south of the southernmost localities seen in the map), Large open rings: more thoroughly studied areas (for details, see p. 236). Small open rings: record of locality not exact or insufficient ('Massachusetts', 'Labrador', 'North Greenland, Norsovak', 'Iceland', 'Spitsbergen, Kobbe Bay', 'Finmarken').

\section{Gammarus zaddachi Sexton subsp. zaddachi Spooner 1947.}

\section{SYNONYMS}

Hoek, I889: G. locusta, var. A. ${ }^{1}$

Sexton, I9I2, I9I3, I942: G. zaddachi, fresh-water form.

Tesch, I9I5: G. locusta, var. ${ }^{1}$

*Stephensen, I9I7: G. locusta var. Zaddachi (in part.); intermediate form between this form and $G$. locusta (in part.). I927: G. duebeni (at least in part.).

*Hellén, I9r9: G. locusta (in part.); G. duebeni (in part.).

Tesch, I922: G. locusta, Hoek's var. A.

1 This form, which already Sexton (I942, p. 582) has regarded as belonging obviously to zaddachi, seems to be identical with $z$. zaddachi, owing to the presence of long setae on pleon segments 4-6 and telson (Hoek's figs. II' and $\mathrm{II}^{\prime \prime}, \mathrm{pl}$. X) and of red spots on the pleon; the extremely low salinity in some of the recorded localities is also a favourable indication.

The two specimens, described by Tesch (1915) from the southern part of the North Sea and regarded by him as closely related to Hoek's var. A, might also belong to z. zaddachi. Their occurrence in the open sea was due presumably to transport from adjacent coastal waters with reduced salinity. 
Gurjanova, I930: G. zaddachi. ${ }^{1}$

Dementieva, I93I: $G$. setosus f. baltica. ${ }^{2}$

Schijfsma, I93I: G. locusta, Hoek's var. A.

*Poulsen, I932: G. duebeni. 1933-36: G. duebeni (in part.).

Oldevig, I933: G. locusta (in part.).

*Segerstråle, I933: G. locusta (in part.). I944: G. zaddachi.

*Schellenberg: G. locusta f. zaddachi (determination of samples, Helsinki Mus.).

Serventy, 1935: G. zaddachi. ${ }^{1}$

*Valovirta, I935: G. locusta f. zaddachi.

Lucks, I937: G. locusta-zaddachi.

Höfken, I937: G. zaddachi.

${ }^{\star}$ Reid, I939: G. sarsi. 1945: G. ochlos nom.nov. (=G. sarsi). ${ }^{3}$

* Suomalainen, I939: G. locusta (in part.).

*Dahl, I944: G. locusta f. zaddachi, G. locusta f. setosus.

\section{MORPHOLOGY}

Maximum size. Male $22 \mathrm{~mm}$., female $\mathrm{I} 5 \mathrm{~mm}$.

Body colour (studied in freshly captured Finnish specimens). Ground colour distinctly lighter than in oceanicus: pale greyish green, sometimes greyish yellow. On the dorsal parts of the body a darker pattern, pale or darker brownish green in colour (Fig. 5). This pattern, the colour intensity and extension of which varies considerably, is composed of a system of transverse and longitudinal bands. ${ }^{4}$ Transverse bands. Present on the posterior margin of head and of all body segments, excepting pleon segments $4-6$ (the colour effect of these bands is augmented by the partial intervention of each segment into the preceding one; on that account these portions seem especially dark). On account of the bands the body of the animal is distinctly transversely striped. On the anterior margin of head, the first peraeon segment, and all pleon segments, transverse bands also occur. Finally, there are median bands on the peraeon segments (excepting the Ist) and on pleon segments I-3 (the pleon bands are comparatively strongly developed). The median bands

${ }^{1}$ In view of the very low salinity in the locality, where Gurjanova captured ' $z a d d a c h i$ ' ('almost fresh' water, in the estuary of the Sewernaja Dvina), she very likely had to do with z. zaddachi. The same conclusion holds good for the specimens caught by Serventy at the more inland stations in the estuary investigated (River Deben, England).

2 The comparatively slight head sinus depicted by Dementieva (fig. ro) is conceivably due to somewhat inaccurate drawing or may refer to a specimen of the true locusta; the telson figured is of typical $z$. zaddachi shape.

${ }^{3}$ The author has found no essential differences between this very small form (length c. $6 \mathrm{~mm}$.), described on material from the brackish Loch of Stennes, Orkney, and mature specimens of $G$. z. zaddachi of the same size from the Baltic (material kindly sent by Mr Reid).

${ }^{4}$ Palmer (1933, p. 65) observed brown transverse bands on the body segments and on the appendages of a form of $G$. zaddachi, captured in brackish water on the English coast; it was probably z. zaddachi or z. salinus. 
are frequently more or less reduced, sometimes missing, even on the pleon. Longitudinal bands. A median band, more strongly developed on the pleon

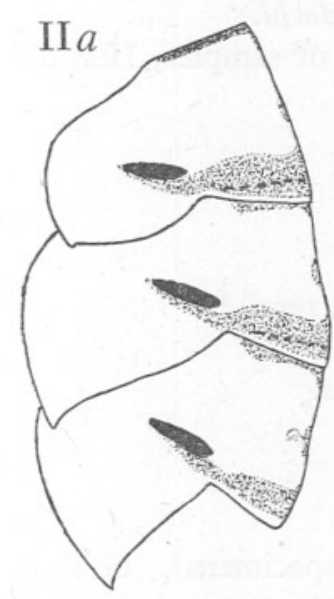

II $b$

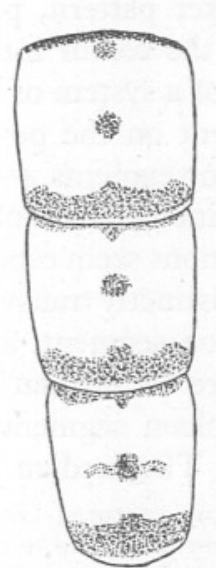

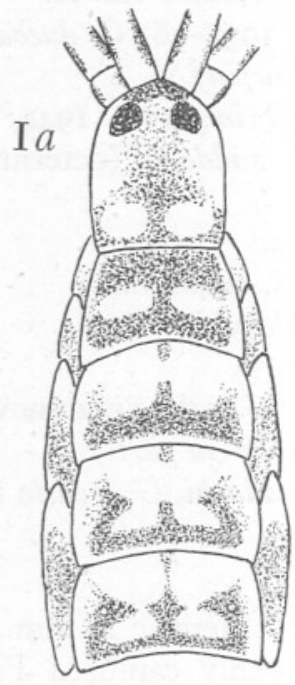

$\mathrm{I} b$

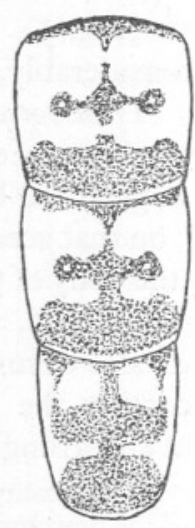

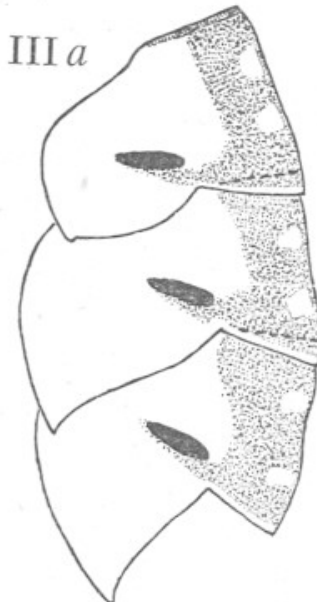

III $b$

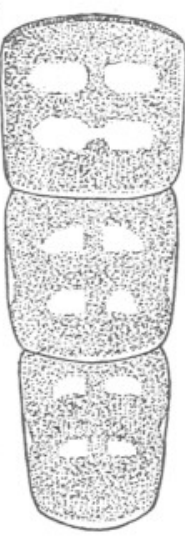

Fig. 5. The pattern in Gammarus z. zaddachi. (Material from the south coast of Finland; males.) Three specimens (partly) depicted, to show variation. I $a$, anterior part of body; I $b$, pleon segments I- 3 of the same animal. II $a$ and III $a$, pleon segments I-3 of two other animals, from the side; II $b$ and III $b$, the same segments from above. The black oblong patches show the position of the red spots of oil globules.

but sometimes even here strongly reduced (see Fig. 5), runs along the whole length of the body. As a rule it is accompanied on both sides by a band, more developed on the peraeon. The colour pattern is observed also on the antennae (peduncle, flagella), on the peraeopods (especially on segments I, 
3, 5-6), uropods and telson, and, weakly, on the side-plates. A pattern resembling the one just mentioned has been described by Sexton (1939) in G. tigrinus.

On the sides of pleon segments I-3 there are almost invariably red spots of 'red oil globules', known from various other species of the genus Gammarus and mentioned in G. zaddachi by Sexton (cf. also Palmer, I933). These are shown in Fig. 5. The pattern and the red spots disappear in preserved animals.

Setose armature of peraeopods, pleon segments $4-6$, telson and uropods. Strong development of the setae, as seen in Sexton's figures (1942, fresh-water form). Last peraeopod, longest seta in subapical cluster on hind margin of segment 5 surpassing end of the segment (Fig. $3 i$ in the present paper). Telson, longest apical seta longer than distance from its insertion to insertion of subbasal spines (Fig. $3 j$ ). Number of telson setae, see below.

Length of antenna 2 in percentages of antenna $\mathrm{I}$, from $\mathrm{I} 7$ males from the Baltic and the Danish lake Lammefjordssöen, length $13-20 \mathrm{~mm} .:$ 78-89, average $84 \%$.

Maximum number of segments in the flagella (body length in brackets):

$$
\begin{aligned}
& \text { Male Female } \\
& \begin{array}{lll}
\text { Antenna I: primary flagellum } & 39(2 \mathrm{~mm} .) & 3 \mathrm{I}(\mathrm{I} 5 \mathrm{~mm} .) \\
\text { accessory flagellum } & 8(20 \mathrm{~mm} .) & 6(15 \mathrm{~mm} .)
\end{array} \\
& \text { Antenna } 2 \text { I9 }(20 \mathrm{~mm} \text {.) I4 ( } 15 \mathrm{~mm} \text {.) }
\end{aligned}
$$

Length of peduncle segments of antenna I (Fig. $3 h$; for measuring method see p. 227). Ratio of length of segments 2 and 3 combined to that of segment I, from I.3:I to I.7:I, generally $c$. I.5:I. Length of segment $3,0.5-0.7$ of that of segment 2. End of peduncle reaching at least to about one-fifth, as a rule to somewhat less than half the length of segment 5 of antenna 2.

Number of hair clusters (including apical cluster) on the under-margin of peduncle segments 2 and 3 in antenna I (Fig. 3). Segment 2, 5-9 clusters, generally $6-7$; segment $3,3-5$, generally 4 .

Pleon segments 4-6, spine formula:

$$
\begin{array}{ll}
\text { 4th segment } & 2-3: 2: 2-3 \\
\text { 5th segment } & 2-3: 2: 2-3 \\
\text { 6th segment } & 2-3: 2: 2-3
\end{array}
$$

Telson, number of spines and setae:

$\begin{array}{lcc} & \text { Spines } & \text { Setae } \\ \text { Apical } & \text { I-3 } & 4-17 \\ \text { Subapical } & \text { O-I } & \text { I-2 } \\ \text { Subbasal } & \text { I } & 2-4\end{array}$

Uropod 3 inner ramus, length about three-quarters that of the outer. 


\section{DisTRIBUTION $^{1}$}

Brackish and, locally, fresh water in north and west Europe (highest salinity recorded $c$. I4-I $8 \%$ o $){ }^{2}$ In the Baltic district found practically only in brackish water (the only exception being the record from the Danish Lake Lammefjordssöen, see below). ${ }^{3}$

Great Britain: see the numerous records given by Spooner. To them may be added Loch of Stennes, Orkney (brackish water, locality for Gammarus ochlos $($ sarsi $)=$ G. z. zaddachi; see p. 23I).

Ireland: Lakes Lough Nadarragh, Lough Keenaghan, Lough Awaddy, Lough Tullynabour, Lough Erne (Sexton, I9I2).

France: Nantes and Belle-Ille-en-Loire (Sexton, I942, p. 583).

Belgium: see Spooner.

Netherlands: mouth of the Rhine and the Waal, Zuiderzee (Hoek, I889; Tesch, I922; and Schijfsma, I93I: G. locusta var. A).

Germany: see Spooner.

Denmark: Lake Lammefjordssöen (north-west Sealand; Copenh. Mus.); for marine localities see below. Spooner also gives several records from Danish waters.

Norway: Bolstadfjorden (near to Bergen; Bergen Mus.).

Baltic: all over the area, throughout the Gulf of Bothnia and the Gulf of Finland, to the Danish waters (for details see pp. 236-8).

? White Sea, mouth of the Sewernaja Dvina (see p. 23I, footnote I).

\section{Gammarus zaddachi Sexton subsp. salinus Spooner I947}

As mentioned previously, in the Gammarus material studied by the author from the Baltic, a form of zaddachi was often found to which a peculiar combination of characteristics of the forms now named $z$. zaddach $i$ and $z$. oceanicus is typical. The peduncle of antenna I is about as setose and elongate as in the former subspecies, whereas the hinder peraeopods, the pleon segments $4-6$, and the telson are almost glabrous, as in the latter.

The opportunity given to the author of reading Spooner's manuscript and our reciprocal examination of British and Finnish material respectively has made it clear that the 'combined' Baltic form is identical with Spooner's subspecies salinus.

As this 'combined' type was captured only in waters where also z. zaddachi and oceanicus occurred, it seemed possible to the author at the first sight that it represented a curious result of crossbreeding between these two forms. Now,

1 In order to make the list more useful it has been completed by references to Spooner.

2 Tesch, I922, Zuiderzee (Hoek's var. A).

${ }^{3}$ Compare Gammarus duebeni, which, in this area, is confined to brackish water, though in western Europe, etc. it is found also in fresh-water localities (cf. Segerstråle, I946). 
however, Spooner's interesting statement of salinus and z. zaddachi being incapable of producing fertile eggs with one another has given evidence of the genetical independence of the former type, and thus has motivated the establishing of it as an independent subspecies.

As already indicated the separation of salinus from zaddachi is easy, whereas the limit between the former subspecies and oceanicus may sometimes appear to be vague, owing to the partial overlapping of the main distinguishing characteristics, viz. the length and setation of the peduncle of antenna I. As to the latter characteristic which is more useful in practice, it is typical that salinus has at least six tufts on the under-margin of peduncle segment 2, against four tufts in typical oceanicus. But the range of variation of both subspecies also includes the tuft number of five, and this number seems to be comparatively common in salinus. As pointed out previously, the number of tufts on the last peduncle segment might, in such instances, be a reliable distinctive characteristic. In oceanicus, from purely marine localities, where the brackish salinus is not to be expected, more than two tufts have practically never been found by the author, whereas salinus $\sigma^{1}$ typically has at least three. ${ }^{1}$ Specimens with five tufts on the second peduncle segment and three on the third might consequently belong to salinus, not to oceanicus. In freshly captured animals also the colour will, presumably, prove to be a good distinctive characteristic. The examination of a number of such specimens of typical salinus from Finnish waters showed that they all had the pattern which is found in z. zaddachi (p. 23I), though it was generally much less distinct than in that form (the red spots were also present in many specimens). Further observations on more extensive material are necessary, but the foregoing statements seem at any rate to make it very likely that the colour will prove an additional characteristic which reliably distinguishes salinus from oceanicus.

In the material from the Baltic specimens have also been observed in which the setation of the last peraeopods, or of the telson (the two characteristics chosen as indicator of the hairiness of the hinder parts of the animal), or of both, is somewhat more strongly developed than in typical oceanicus. The setose armature of antenna $I$ in these specimens is never as sparse as in typical oceanicus. The author is inclined to suppose that these varieties belong to salinus.

Details of the distribution of salinus in the Baltic, as well as in Danish waters, are given in the following section. Regarding the occurrence of the subspecies outside this district, see Spooner (pp. $4 \mathrm{I}-3$ ).

1 The only exception refers to a couple of specimens observed in the material from Heligoland. They bear three hair clusters on the segment in question, and the length of the last peduncle segment compared with the length of the second segment is 0.6 , against at most two and 0.5 respectively in the typical marine form. It does not seem quite impossible that these specimens have been transported to Heligoland from adjacent brackish waters on the continental coast (cf. the assumed transport in another case, p. 230, note I). 


\section{The Distribution of GAMMARUS ZADDACHI AND G. LOCUSTA IN CERTAIN WATERS}

\section{The Baltic and Denmark (excluding Randers Fjord and Ringköbing Fjord)}

Material. Number of samples investigated (abbreviations of Museum names: Cop. $=$ Copenhagen, Hels. $=$ Helsinki-Helsingfors, St. $=$ Stockholm): Finnish waters, c. 230 (Hels., and the author's collections); the archipelago from Stockholm to Kalmar, I2 (St.); coast of Blekinge, 4 (St.); Gothland, 20 (St.); Bornholm, 5 (St., Cop.); Danzig, I (St.); east of Rügen, 2 (Cop.); Rügen-Danish Isles, I2 (Cop.); The Sound, 3 (Cop., St.); Falster-Sealand, 6 (Cop.); Great Belt, 6 (Cop.); Little Belt and adjacent southern waters, 3 (Cop.); Ise Fjord, 2 (Cop.); Cattegat, Io (Cop.); west coast of Denmark, 5 (Cop.).

Regarding the literature records, the surveys by Stephensen (I928, I929), Oldevig (I933) and Schellenberg (I942) could not be used, as the differences between G. locusta and zaddachi are here not recognized. But the data published by Poulsen (I932) and Dahl (1944), though not correct in the species determinations, can be reinterpreted in the light of the samples of these authors' material available to the writer. From the south coast of the Baltic G. zaddachi oceanicus has been recorded (as saline form) by Sexton (I9I2, I9I3) who also records, and figures, locusta from these waters.

Gammarus zaddachi oceanicus. This form is the main Gammarus in the Baltic and around the Danish Isles. It is lacking only in the 'innermost' parts of the Gulf of Bothnia and of the Gulf of Finland (Fig. 6; in the Gulf of Bothnia, which has been studied less thoroughly, the northernmost record of oceanicus is c. $63^{\circ} 30^{\prime} \mathrm{N}$.) and other strongly diluted localities. In the Gulf of Finland the 'innermost' records (Virolahti: Kiuskeri and Pien Kalastaja) lie at the isohaline of c. $2.5 \%$ salinity (surface, year average). On the south coast of Finland, from which area a great quantity of material has been investigated, the form in question greatly outnumbers $z$. zaddachi in the outer parts of the archipelago, at least as far eastward as in Pellinge, and even in a sample from the island Peninsaari (near Lavansaari, at $28^{\circ} 2^{\prime}$ E.) oceanicus is clearly predominating (II5 oceanicus against $4 z$. zaddachi). On the Finnish coast oceanicus is especially common in the Fucus vegetation (cf. Segerstråle, I944; oceanicus here called G. locusta f. typica). The bulk of the material of oceanicus originates from a depth of a few metres, but there are also a number of samples from the open sea between Rügen and the Danish Isles with depths of c. $20 \mathrm{~m}$.

In the samples from the Cattegat oceanicus is sparsely represented and entirely lacking in the material from the Dariish west coast.

Gammarus zaddachi zaddachi is represented in the material from the very end of the Gulf of Bothnia and the Gulf of Finland to the Sound (Isle Hven). In the 'innermost' parts of the Gulfs (Fig. 6) and other strongly diluted areas it is the only abundant Gammarus (in addition G. duebeni occurs here locally; cf. Segerstråle, 1946). The author found the amphipod in great numbers inhabiting the vegetation of Phragmites in estuarine localities. The animal is 


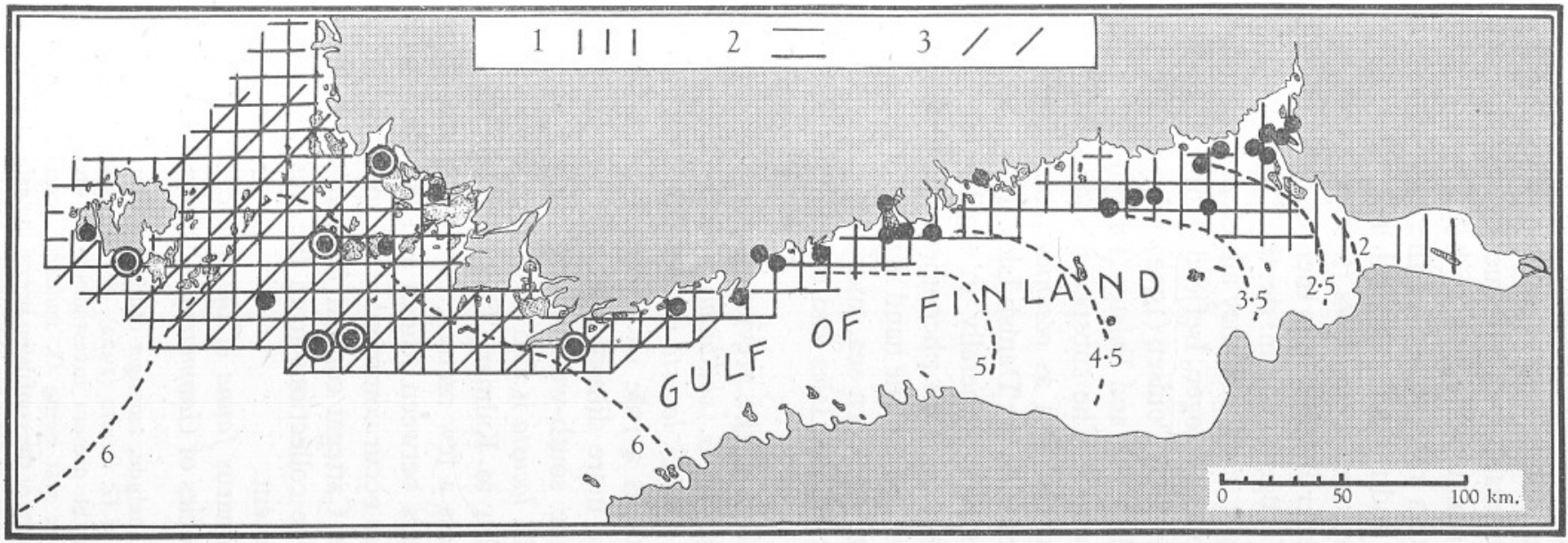

Fig. 6. The occurrence of Gammarus zaddachi zaddachi (I), G. zaddachi oceanicus (2), and G. locusta (3) along the north coast of the Gulf of Finland and in the south-west Finnish waters. The black dots show the origin of the material investigated. Localities for G. locusta indicated by rings. As seen, there are three Gammarus zones: (a) in the innermost part of the Gulf only G.z. zaddach occurs, $(b)$ westward from here to near the mouth of the Gulf oceanicus also is found, $(c)$ the south-west waters are inhabited, in addition, by G. locusta. In addition, G. z. salinus occurs in the area, having about the same distribution as does oceanicus. Broken lines represent isohalines $(\%)$. 
common also in the Finnish archipelago, but, as mentioned above, less numerous than oceanicus in the Fucus vegetation of the outer zone. However, it generally occurs considerably more frequently than does oceanicus in very shallow water (with a maximum depth of half a metre or so) in this zone. From the Swedish waters represented in the material, i.e. the coast from Stockholm to Blekinge, and the coast of Gothland, there are numerous finds; also Dahl frequently captured z. zaddachi (for synonymy, see p. 23I) in the latter waters. From deeper Baltic waters there is only one sample containing z. zaddachi taken east of Rügen, in $2 \mathrm{I} \mathrm{m}$. depth. The Danish material includes some samples containing z. zaddachi; they all refer to a depth of at most a few metres (Ore Strand: Sliphavnskrogen, Isefjord: Hovvig). But from this district there are also records given by Poulsen (1932), who captured the form in the waters between Sealand, Möen and Falster (for synonymy, see p. 23I).

Gammarus zaddachi salinus. The subspecies shows, on the whole, the same limits of distribution in the area as oceanicus, but it is not present in the material from localities outside the Danish Isles. The type in question is found in most Gammarus samples, generally in small numbers, but locally it occurs in striking abundance. This phenomenon is observed in localities of quite different natures, viz. on the one hand in parts of the Finnish archipelago, which are not exposed to the open sea, and on the other in the open waters between Rügen and the Danish Isles and on the coast of the Great Belt (at Nyborg).

Gammarus locusta. Most of the previous records of this species from the Baltic area actually refer to G. zaddachi, mainly to subsp. oceanicus (for synonymy, see p. 227). ${ }^{1}$ But G. locusta is also widely distributed in the Baltic district, though it is not as a rule so abundant as zaddachi and does not penetrate as far into the more diluted waters. Thus locusta on the Finnish coasts is confined to the south-west waters with a minimum salinity of c. 5-6\% (see Fig. 6). G. locusta is also missing in the Swedish samples from the waters off Stockholm to Kalmar. The depth in the places of capture generally does not surpass a few metres; in the material from the open and comparatively deep waters between Rügen and the Danish Isles, where zaddachi oceanicus and salinus occur commonly, the species is practically missing.

The samples from the Cattegat contain locusta in much greater numbers than zaddachi, and in the collections from the west coast of Denmark only the former species is present.

Summary of the Gammarus fauna of the Baltic. The forms treated above are the only common species of Gammarus of this area. Besides them the area

1 The Danish collections include, amongst other, the material used by Blegvad for his investigation on the biology of G. locusta (I922). Of c. 210 specimens from this collection, examined in connexion with the present investigation, $c$. one-third (70 specimens) proved to belong to this species, the rest being G. zaddachi oceanicus, and salinus. This result is by no means surprising in view of the confusion prevailing especially in earlier years. Blegvad also observed that the specimens studied by him varied greatly. 
seems to harbour only $G$. duebeni, which is confined to very shallow water and to speciallocalities (it occurs mainly in brackish rockpools and similar small basins on the shore of islands, exposed to the sea; see Segerstråle, 1946). There is no evidence for the occurrence of G. setosus Dement. Dementieva's G. setosus f. baltica and Dahl's G. locusta f. setosus from Baltic localities are attributed to G. z. zaddachi (see synonyms, p. 23I).

\section{Randers Fjord}

A comparatively large collection of Gammarus, made by Johansen and Ussing during their investigations of the invertebrate fauna of this water, situated on the north-east coast of Jutland in Denmark and interesting because of the decreasing salinity from the mouth to the more inland parts, is discussed in Stephensen's paper of I9I7. He records the following species and forms from the area: $G$. locusta, $G$. locusta var. Zaddachi, an intermediate form between $G$. locusta and this form, as well as $G$. duebeni and G. pulex. Later on, in 1927 , Stephensen identifies some of the intermediates between $G$. locusta and $G$. locusta var. Zaddachi as G. duebeni. The material concerned was deposited in the Museum of Copenhagen, and all of it, excepting that of G. pulex and $G$. duebeni, was kindly sent by Mr Stephensen to the author, who has thus had the opportunity of going through it.

The results are as follows. Most specimens labelled $G$. locusta are correctly determined (one being an intermediate between the subspp. oceanicus and zaddachi of G. zaddachi). The form called G. locusta var. Zaddachi is mainly G. z. zaddachi, whereas the 'intermediate form between G. locusta and G. locusta var. Zaddachi' includes all three subspecies of G. zaddachi; in addition, there are some $G$. locusta and one $G$. duebeni (this species captured at St. 9, depth o m.). In a number of samples of $G$. zaddachi, the subspecies could not be determined, on account of the very small size of the animals. The study of the material has given the following ranges of distribution:
G. zaddachi zaddachi:
St. 2 (salinity from $\mathrm{I}-2$ to $\mathrm{I} 2 \%$ ) oceanicus:
St. 8-IO (salinity from 5 to at least $24 \%$ )
G. locusta:
St. Io (salinity from c. I7 to at least $24 \%$ ).

As seen from the above records the subspecies of zaddachi, as well as locusta, follow one another in the same order as in the Baltic area. The salinities at the most inland localities for z. oceanicus and for locusta, are higher in Randers Fjord than in the Baltic, but this phenomenon is obviously due to the comparatively scanty material from the Fjord.

\section{Ringköbing Fjord}

This water, located on the west coast of Jutland, is connected with the North Sea through only a narrow opening. The water is consequently brackish, the (surface) salinity averaging in the main part of the area $c .4-8 \%$. The 
Gammarus fauna has been treated by Poulsen (I933-6). He records the following species: $G$. locusta, occurring only in the very opening of the Fjord; $G$. duebeni, common everywhere, excepting in the saltest part, and observed also in the lowermost course of the river Vondaa; G. zaddachi, found only in a small basin, which is separated both from the Fjord and from the North Sea.

Fortunately, the collection received for the present investigation from the Copenhagen Museum includes about forty samples of the Ringköbing Fjord material (the determination, however, is not given on the labels), thus enabling the author to check the records which were given by Poulsen and of which some appeared doubtful.

The results are as follows. (I) The main Gammarus of the Fjord is not duebeni, but zaddachi. All the specimens of this species, which are large enough to be identified, belong to z. zaddachi. G. duebeni is certainly present in the material, but occurs only in a few samples, all taken in very shallow water (0-0.5 m.). The localities are: the mouth of the River Vondaa; near the bridge in this river; off Gammelsogns Mölle; on the shore c. $200 \mathrm{~m}$. east of the mouth of the River Falen; Gjödel Canal, near the bridge at Lönne Klit.

(2) G. z. zaddachi occurred in different parts of the Fjord, from the shore to open areas with depths of $c .3 \mathrm{~m}$. (maximum depth of the area c. $6 \mathrm{~m}$.). In addition, one sample has been collected in the mouth of the River Vondaa, near the bridge (3 July I92I).

(3) The true locusta was found only in one sample (Söndre Dyb, $3.5 \mathrm{~m}$.). Poulsen records the species from the saltest parts of the Fjord. These samples are lacking in the material available to the present author, but as the characteristics given for this species by Poulsen are quite correct there is no reason to doubt these determinations.

(4) The ' $G$. zaddachi' mentioned in Poulsen's paper seems not to be included in the preserved material, but the illustrations given suggest that the form of the species in question is oceanicus.

\section{The Relationship BETWEEN GAMMARUS ZADDACHI AND THE SPECIES G. SETOSUS AND G. WILKITZKII}

In the material from the Arctic there are numerous samples containing the large species $G$. setosus and $G$. wilkitzkii (many of the samples are labelled G. locusta), thus enabling the author to compare them with G. zaddachi.

G. setosus (material: about thirty-five samples from Arctic Canada, Greenland, Iceland, Spitsbergen, east coast of Murman, Novaya Zemlya, Kara Sea, the Arctic Sea off Siberia). This species was separated from G. locusta and established as an independent species by Dementieva (I93I), mainly on material from Arctic waters (the amphipod regarded by this author as a Baltic form of setosus is obviously identical with G. z. zaddachi). Stephensen 
(I940) records it as G. locusta subsp. setosus, and gives the first accurate description of the form.

The examination of the specimens in the present material showed that the species is as little allied to the true locusta as is zaddachi, but there is a close relation between setosus and the last-mentioned species, especially subsp. oceanicus. As in zaddachi the head sinus is deep, the 4 th side-plate has the same semicircular lower margin, the pleon epimera show no difference in shape, the last uropods have the inner ramus of the same relative length, and as to the relative length of the peduncle of antenna I there is a strict agreement with zaddachi oceanicus.

The main differences are as follows. (I) The common occurrence of plumose setae in setosus, particularly on peraeopods 5-7 (segments 4-6), pleon segments
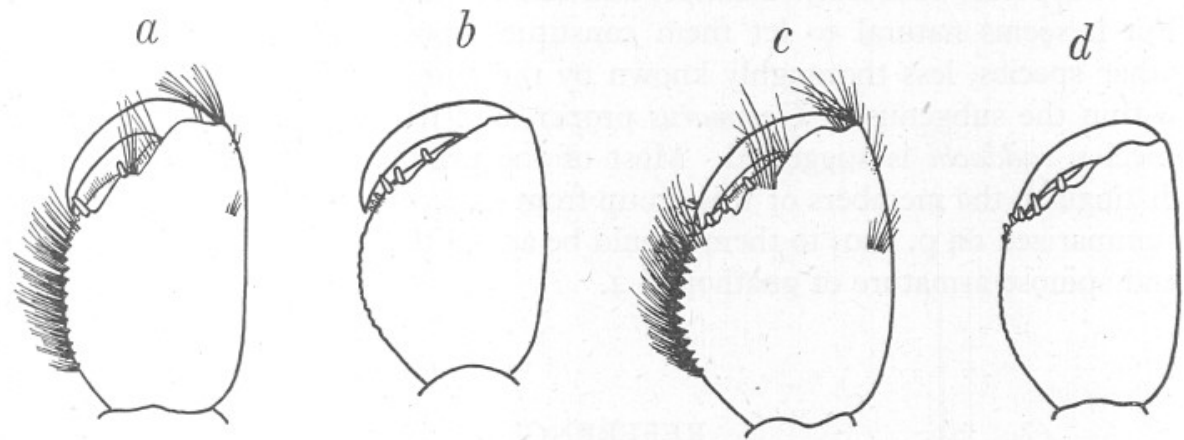

Fig. 7. Second gnathopods of Gammarus zaddachi oceanicus $(a, b)$ and Gammarus setosus $(c, d)$ (males) to show variation in shape. a, oceanicus, typical (Murman Coast, body length $30 \mathrm{~mm}$.). b, oceanicus, approaching typical setosus (Spitsbergen, $25 \mathrm{~mm}$.). c, setosus, typical (east Greenland, $32 \mathrm{~mm}$.). d, setosus, approaching typical oceanicus (the Arctic Sea off Siberia, $26 \mathrm{~mm}$.). In $b$ and $d$ the setae are omitted.

4-6, and the telson; here practically all the setae are feathery (cf. Stephensen, I940, fig. 4I). In addition the apical hairs on the telson are markedly longer than in z. oceanicus (in the male about three times as long as the corresponding spines (or longer), against at most about twice the length in $z$. oceanicus). (2) The 2nd and 3rd peduncle segments of antenna I bear hair clusters, on the under side, from 5 to about 7 , and $2-3$ respectively, whereas $z$. oceanicus has 3-5 and I-2 respectively. (3) The eyes are generally distinctly smaller in setosus. (4) The 2nd gnathopod in this species is as a rule considerably stouter and its hind margin much more bulging; besides, the gap between the midpalm spine, present in the male, and the palmar-angle spine-row is usually far less pronounced (Fig. 7) (in addition, in the female the latter spine group occupies a greater part of the palma in setosus than in z. oceanicus).

According to the author's observations only the characteristics mentioned above under (I) always separate setosus from zaddachi oceanicus, whereas, when comparing the former species with large specimens of oceanicus, the other 
characteristics may overlap more or less (Fig. 7). Even in the occurrence of feathery setae there may be some transition, oceanicus occasionally having single plumose hairs on the last uropods, pleon segments, and telson (Fig. $3 f$ ), but the difference is nevertheless very marked.

Besides $G$. setosus, the very large Arctic species G. wilkitzkii (length up to $48 \mathrm{~mm}$.; Gurjanova, 1930) is closely allied to zaddachi. It has even been reported by some writers, amongst others Stephensen, as possibly being identical with this species. In fact, the differences between z. zaddachi and wilkitzkii are small. ${ }^{1}$ They seem, however, to be great enough to justify retaining the latter as an independent species, as suggested by Sexton (I942). The same conclusion appears to hold good regarding setosus. If these two forms were considered subspecies of zaddachi, the still closer relation between the subspecies zaddachi, oceanicus, and salinus would not be so clearly seen. But it seems natural to let them constitute-possibly together with some other species, less thoroughly known by the author-an independent group within the subgenus of Gammarus proper, and naming this group after the species zaddachi is suggested. Most of the principal characteristics which distinguish the members of this group from $G$. locusta are the same as those summarized on p. 220; to them should be added the differences in the shape and spinose armature of gnathopod 2.

\section{REFERENCES}

Blegvad, H., I922. On the biology of some Danish gammarids and mysids. Rep. Dan. Biol. Sta., Vol. 28, pp. I-IO3.

DaHL, E., I944. The Swedish brackish water Malacostraca. Kungl. Fysiogr. Sällsk. Lund Förhandl., Bd. I4, Nr. 9, I7 pp.

Dementieva, T., I93I. On the variability of the Amphipoda of the northern seas. Trans. Oceanogr. Inst. Moscow, Vol. I, pp. 65-82.

GurJanova, E., 1930. Beiträge zur Fauna der Crustacea-Malacostraca des arktischen Gebietes. Zool. Anz., Bd. 86, pp. 23I-48.

Hellén, W., I9I9. Zur Kenntnis der Amphipoden-Fauna Finnlands. Medd. Soc. Fauna Flora Fennica, Bd. 45.

Hokk, P. P. C., I889. Crustacea Neerlandica. II. Tijdschr. Nederl. Dierk. Vereen., Ser. 2, D. II, pp. I70-234.

HÖFKEN, U., I937. Statistische und experimentelle Untersuchungen über die Variabilität von Gammarus locusta (L.). Kieler Meeresforsch., Bd. II, pp. II648.

LILJEBORG, V., I855. Öfversigt af de inom Skandinavien hittills funna arterna af slägtet Gammarus Fabr. Kongl. Vetensk.-Akad. Handl. för är I853. Stockholm.

1 The following divergence observed in material investigated by the author may be added to those listed by Sexton (I942). The peduncle of antenna I is still longer than in $z . z a d d a c h i$, viz. as long as the distance from tip of rostrum to hind margin of peraeon segment 2 ; in $z$. $z$ addach $i$ the peduncle reaches at the most to the middle of the said segment. 
Linnaeus, C., I745. Carl. Linnaei Öländska och Gothländska Resa, etc. Stockholm och Upsala.

- I76r. Fauna Suecica. Stockholm.

Lucks, R., I937. Die Crustaceen und Rotatorien des Messinasees. Ber. Westpreuss. Bot. Zool. Ver. Danzig, Bd. 59, pp. 59-ror.

Milne Edwards, H., I840. Histoire naturelle des crustacées, T. III. Paris.

Oldevig, H., I933. Sveriges amphipoder. Göteborgs Kungl. Vetensk.-och Vitterh.Samh. Handl., Femte följden, Ser. B, Bd. 3, pp. 197-9.

PALMer, R., I933. Notes on Gammarus zaddachi Sexton from Essex, with observations on eye-variations in this species. Ann. Mag. Nat. Hist., Ser. Io, Vol. xI, pp. 64-7.

PoulSEN, E. M., I932. On a collection of Gammarus from the waters south of Sealand. Vidensk. Meddel. Dansk naturh. Foren. Kjöbenhavn, Bd. 94, pp. I-I2.

— 1933-6. Malacostraca og Cirripedia. In Ringköbing Fjords Naturhistorie i Brakvandsperioden I915-I93I. Copenhagen.

ReID, D. M., I939. Gammarus sarsi sp.n. (Crustacea, Amphipoda). Ann. Mag. Nat. Hist., Ser. II, Vol. x, pp. 28I-5.

- 1945. Gammarus ochlos (nom.nov.), Crustacea, Amphipoda. Ann. Mag. Nat. Hist., Ser. II, Vol. I2, pp. 637-8.

Schellenberg, A., I934. Zur Amphipodenfauna der Kieler Bucht. Schr. Naturwiss. Ver. Schleswig-Holstein, Bd. 2, pp. I-I6.

- 1942. Flohkrebse oder Amphipoda. In Die Tierwelt Deutschlands und der angrenzenden Meeresteile. Jena.

SchiJfsMA, K., I93I. Amphipoda van de Zuiderzee (I927-I929). In De Biologie van de Zuiderzee tijdens haar drooglegging. Meded. van de Zuiderzee-Commissie, Nr. 3. Den Helder.

Segerstrấle, S. G., I933. Studien über die Bodentierwelt in südfinnländischen Küstengewässern. II. Ưbersicht über die Bodentierwelt, mit besonderer Berücksichtigung der Produktionsverhältnisse. Soc. Scient. Fennica, Comment. Biol., Iv, No. 9, 79 pp.

— I944. Weitere Studien über die Tierwelt der Fucus-Vegetation an der Südküste Finnlands. Soc. Scient. Fennica, Comment. Biol., Ix, No. 4.

- 1946. On the occurrence of the amphipod, Gammarus duebeni Lillj. in Finland, with notes on the ecology of the species. Soc. Scient. Fennica, Comment. Biol., IX, No. I8, 22 pp.

SERVENTY, D. L., I935. Observations on Gammarus zaddachi Sexton, an estuarine amphipod, and associated forms. Internat. Rev. gesamt. Hydrobiol. Hydrogr., Bd. 32, pp. 285-94.

Sexton, E. W., I9I2. Some brackish-water Amphipoda from the mouths of the Weser and the Elbe, and from the Baltic. Proc. Zool. Soc. London, I912, pp. 656-65.

- I9I3. On a collection of Gammarus from the Königsberg Museum. Schr. Phys.ökon. Ges. z. Königsberg i. Pr., Bd. 54, pp. 90-4.

- 1939. On a new species of Gammarus (G. tigrinus) from Droitwich district. fourn. Mar. Biol. Assoc., Vol. xxiII, pp. 543-5I.

- I942. The relation of Gammarus zaddachi Sexton to some other species of Gammarus occurring in fresh, estuarine and marine waters. Fourn. Mar. Biol. Assoc., Vol. xxv, pp. 575-606.

SPOONER, G. M., I947. The distribution of Gammarus species in estuaries. Part I. fourn. Mar. Biol. Assoc., Vol. xxviI, pp. I-52.

Stephensen, K., I9I7. On a collection of Gammarus from Randers Fjord, Denmark. Vidensk. Meddel. Dansk Naturhist. Foren., Bd. 68, pp. 37-50. 
STEPHENSEN, K., 1927. Revideret Fortegnelse over Danmarks Arter af Amphipoda (3. Del: Gammaridea: Fam. Gammaridae til Fam. Podoceridae (Dulichiidae aut.); Caprellidae). Vidensk. Meddel. Dansk Naturhist. Foren., Bd. 84, pp. II5-20.

- 1928. Tanglopper (Amfipoder). In Danmarks Fauna. Copenhagen.

I929. Amphipoda. In Die Tierwelt der Nord- und Ostsee, Lief. xIv, Teil x $f$.

1940. The Amphipoda of N. Norway and Spitsbergen with adjacent waters. Tromsö Museums Skr., Vol. III, pp. 279-362.

Suomalainen, H.; I939. Beiträge zur Kenntnis der Verbreitung der marinen Bodentierwelt im östlichen Teil des Finnischen Meerbusens. Ann. Zool. Soc. Zool.Botan. Fennicae Vanamo, Bd. 6.

Tesch, J. J., I915. De Amphipoden der Zuidelijke Nordzee verzameld met de 'Wodan'. Rapp. Rijksinst. Vissch. underzoek, D. I, pp. 336-9.

- 1922. Amphipoden. In Flora en Fauna der Zuiderzee. Den Helder.

VAlovirTA, E. J., I935. Über die Verbreitung einiger Bodentiere im Bottnischen Meerbusen. Ann. Zool. Soc. Zool.-Bot. Fennicae Vanamo, Bd. I, pp. I2-I4.

ZADDACH, G., I844. Synopseos Crustaceorum prussicorum prodromus. Regiomonti.

1878. Die Meeres-Fauna an der preussischen Küste. Schr. Phys.ökon. Ges. z. Königsberg i. Pr., Jhrg. 19, pp. 26-32. 


\title{
THE STRUCTURE, TADPOLE AND BUDDING OF THE ASCIDIAN PYCNOCLAVELLA AURILUCENS GARSTANG
}

\author{
By N. J. Berrill \\ From the Plymouth Laboratory and McGill University, Montreal
}

(Text-figs. I-3)

Pycnoclavella aurilucens was recorded and briefly described by Garstang in I89I from a limited locality in the Plymouth area, and has not been found with certainty of identification from any other region. There has been a tendency to subordinate it as a species of Clavelina, but the dissimilarities are greater even than the original description implies and this procedure is not justified. The genus is accordingly retained, and a more detailed account of the colony, with the first description of the tadpole larva and process of budding, is presented.

Colonies are usually found growing on gorgonians, large hydroids and calcareous algae at depths of $25-30 \mathrm{~m}$. associated with coarse shell gravel and polyzoa such as Lepralia. It is known to occur only in the Plymouth region, unless the form known as Clavelina nana reported from Roscoff and Banyuls (Giard, 1873, Lahille, 1890) turns out to be identical with it. The external appearance of the colonies and of the constituent zooids has been well described by Garstang in the second volume of this fournal. In brief, the colonies are encrusting, the thoracic parts of the small delicate zooids extending freely from a greenish matrix in which the abdomens are embedded. The endostyle and peripharyngeal bands are picked out in yellow or white pigment and are very striking; the zooids are very contractile.

\section{STRUCTURE OF THE ZOOID}

The zooids (Fig. I) in general structure are much like those of Clavelina. They are much smaller and consequently have a less elaborate branchial sac, there being seven rows of gill-slits, rarely eight or nine. The endostyle is comparatively massive, as noted by Garstang, and the siphons independent and without lobes as is in other members of the Clavelinidae. Dorsal languets, corresponding in number to the rows of stigmata, occur along the dorsal line of the branchial sac. The oesophagus is long, the stomach squarish in crosssection as in Clavelina and leading into a typical post-stomach, the latter in turn connected with the intestine proper by a vertically aligned mid-intestine. The rectum opens into the atrial cavity level with the most posterior row of 